\title{
CZU: 635.64:632.38 \\ https://doi.org/10.53040/gppb7.2021.41 \\ EVALUAREA ROLULUI GENOTIPULUI ÎN RĂSPUNSUL ANTIOXIDATIV LA TOMATELE INFECTATE CU VIRUSURI
}

\author{
Mărîi Liliana ${ }^{1}$, Andronic Larisa ${ }^{1}$, Smerea Svetlana ${ }^{1}$, Balașova Natalia ${ }^{2}$ \\ ${ }^{1}$ Institutul de Genetică, Fiziologie și Protecție a Plantelor, Chișinău, Republica Moldova, \\ ${ }^{2}$ Instituția Federală de Stat Științifică Bugetară „,Centrul Științific Federal pentru Legume”, Regiunea \\ Moscova, Federația Rusă \\ e-mail: liliana.marii@igfpp.md
}

\begin{abstract}
Studying the particularities of manifestation of defensive indicators - POX and PPO in case of infection with 2 types of viruses of different virus-host combinations (sensitive, tolerant, resistant) was performed in basis of analysis of variance. The obtained results denote a significant contribution of all analyzed factors in the variability of PPO and POX indices, the major contribution returning to the genotype, followed by viral infection, the type of viral infection with a variable dose of contribution depending on the applied matrix. The PPO index expressed a higher specificity of the genotype response depending on the virus applied compared to POX. At the same time, it was found that TAV had a higher contribution in the variability of POX and PPO, compared to TMV.
\end{abstract}

Key words: viral infection, tomatoes, analysis of variance, antioxidant response

\section{Introducere}

Relațiile plantelor cu patogenii includ un șir de reacții de răspuns, pentru a diminua efectele provocate de pătrunderea intrusului în organismul gazdă. Declanșarea mecanismelor de apărare în cazul interacțiunilor incompatibile duce la manifestarea răspunsului hipersenzitiv (RH) asociat cu localizarea infecției, iar interacțiunea compatibilă, se finalizează cu producerea infecției [1]. Stresul oxidativ și răspunsul anitioxidativ asociat cu interacțiunea plantă-virus sunt elemente primordiale în vederea producerii infecției sau limitării răspândirii ei. Enzimele defensive precum peroxidaza (POX) și polifenoloxidaza (PPO) sunt atribuite reacțiilor de răspuns ale plantelor la stres [2]. În cazul creșterii nivelului activității peroxidazei ca urmare a unei rezistențe sistemice induse, are loc sinteza rapidă a speciilor reactive de oxigen ce duc la moartea celulei și inhibă activitatea patogenului, totodată efectele și rolul POX pot fi foarte variate în funcție de combinația virus - gazdă [3]. Activitatea polifenoloxidazei este importantă la etapele incipiente ale reacției de răspuns a plantei, când are loc distrugerea integrității membranei celulare și are loc eliberarea compușilor fenolici. PPO catalizează oxidarea fenolilor astfel creând un mediu nefavorabil dezvoltării patogenilor [4].

Ameliorarea culturii tomatelor este distinsă de existența unor genotipuri cu gene de rezistență (Sw, Ty sau Tm) la câteva virusuri, inclusiv și VMT [5]. Trei gene asociate rezistenței la VMT, Tm1, Tm2 și $T m 2^{2}$, identificate în speciile spontane și introduse în specia de cultură au fost folosite și în cercetările actuale. Principiul de acțiune al genei Tm-1 e legat de inhibarea replicării ARN-ului viral [6], iar a genelor $T m 2$ și $T m 2^{2}$ de limitarea deplasării particulelor virale [7]. În studiile recente este dovedit efectul genei $T m 2^{2}$ împotriva mai multor tipuri de virusuri [8].

În cercetările prezente sunt reflectate aspecte ce țin de evaluarea contribuției unor factori prestabiliți, în manifestarea reacțiilor enzimatice defensive, POX și PPO, a genotipurilor de tomate la infectarea cu VMT sau VAT.

\section{Materiale şi metode}

In calitate de material biologic au servit plantele a 5 genotipuri de tomate, cu diferit statut genetic şi diferită reacție de răspuns la infectare cu VMT: sensibil - soiul Elvira, tolerant S. pimpinellifolium, rezistent - 3 genotipuri: Rufina (Tm-1/Tm-2 $2^{2}$, Craigella (Tm- $\left.2^{2} / \mathrm{Tm}-2^{2}\right)$ şi Craigella (Tm-1/Tm-1).

Experiențele au fost realizate în condiții de solariu. Fiecare din cele 5 genotipuri, a fost reprezentat de 3 variante: martor, VMT sau VAT (excepție genotipul Rufina, care a fost infectat doar cu VAT). Lotul martor a reprezentat plante ce nu au fost supuse infectării, iar lotul virus - plante infectate. Plantele au 
fost inoculate cu VAT şi VMT la etapa de 4-6 frunzuliţe. Manifestarea simptomelor specifice s-a atestat la cca 20 zile după inoculare. Prezența particulelor virale în plantele inoculate a fost confirmată prin intermediul procedeului de microscopie electronică prin contrastare negativă [9]. Au fost etichetate câte 3 plante de la care au fost colectate frunze din etajele superioare celor supuse inoculării, care au servit drept sursă pentru izolarea proteinelor şi determinarea activităţii peroxidazei acide (POX) şi a polifenoloxidazei (PPO) [10] cu ajutorul spectrofotometrului, în baza modificării dinamice a densităţii optice a soluțiilor. Experiențele au fost realizate în 3 repetiții biologice și 3 analitice.

Prelucrarea statistică a datelor a fost realizată cu ajutorul pachetului de programe Statgraphics Plus 5.1. În baza valorilor Sumei pătratelor din analiza varianței a fost calculată contribuția factorului $(\mathrm{CF})$ în diferențele dintre valorile medii ale variantelor.

\section{Rezultate şi discuţii}

Variația indicilor activității antioxidative (POX, PPO) a tomatelor atestată în cazul acțiunii infecțiilor virale rezultă din particularităţile defensive ale sistemelor plantă-virus (compatibil-incompatibil) și de însăţi specificitatea reacțiilor enzimatice la stres. Includerea în schema de analiză concomitent a mai multor factori complică interpretarea rezultatului prin prisma unor indicatori statistici cu tendințe (creștere, diminuare), și semnificații neunivoce, după cum este parțial redat în figura 1. În acest scop a fost aplicată analiza varianței care permite să stabilim dacă există diferențte între valorile medii a mai multor variante sau grupuri analizate după același indice.
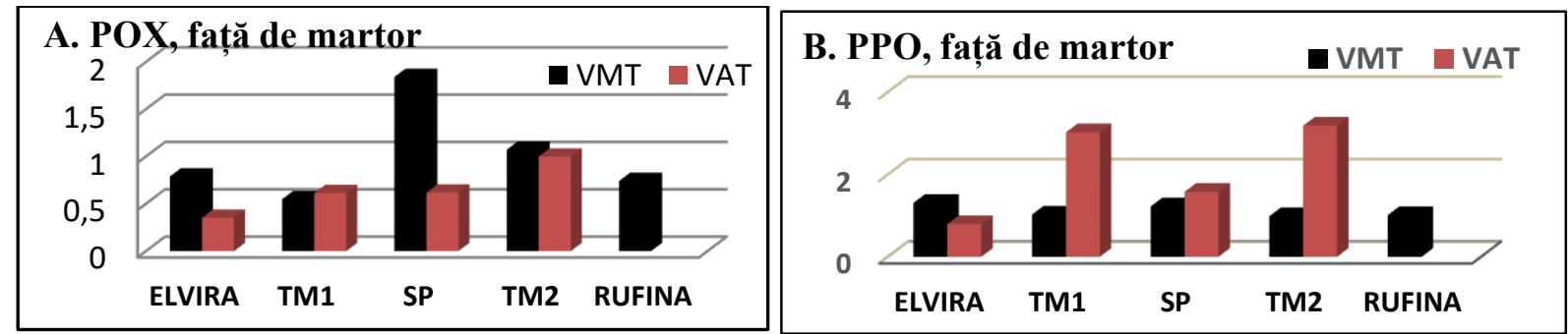

Figura 1. Valorile relative ale indicilor POX (A) și PPO (B) în variantele infectate cu VMT sau VAT raportate la martor.

Analizele preventive au stabilit o dependență semnificativă a variației indicilor POX și PPO în funcție de genotip, prezența infecției virale și tipul virusului aplicat (Tabelul 1). Astfel, contribuția (CF) cea mai mare în variabilitate revine genotipului $(32,5 \%)$ la analiza indicelui POX, iar pentru PPO acesta este devansat de tipul virusului aplicat - VMT sau VAT $(29,8 \%)$.

Reieșind din cele menționate, precum și luând în calcul particularitățile acțiunii fiecărui tip de infecție virală asupra genotipurilor de tomate, particularitățile genotipurilor, dar și specificitatea de acțiune a reacțiilor antioxidative, s-a realizat analiza separată a indicilor POX și PPO pentru fiecare tip de infecție VMT și VAT, precum și alți factori cu diferite grade libertate determinați de schema experienței.

Tabelul 1. Analiza varianței POX și PPO în funcție de genotip, infecție virală și tipul infecției virale (VMT, VAT)

\begin{tabular}{|c|c|c|c|c|c|c|c|c|}
\hline Sursa variaţiei & SP & CF & GL & F & SP & CF & GL & F \\
\hline \multicolumn{4}{|c|}{ POX } & \multicolumn{3}{|c|}{} & \multicolumn{5}{|c|}{ PPO } \\
\hline Genotip & 0,826663 & 32,5 & 4 & $22,85^{* * *}$ & 0,204391 & 24,0 & 4 & $20,44 * * *$ \\
\hline Infecție virală & 0,221496 & 8,7 & 1 & $24,49^{* * *}$ & 0,103807 & 12,2 & 1 & $41,52 * * *$ \\
\hline Tipul virusului & 0,191412 & 7,5 & 1 & $21,16^{* * *}$ & 0,253944 & 29,8 & 1 & $101,57 * * *$ \\
\hline total & 2,54699 & & 149 & & 0,851506 & & 155 & \\
\hline
\end{tabular}

POX. Conform rezultatelor analizei varianței, constatăm că, la infectarea cu VMT sau VAT, atât genotipul, infecția virală, cât și interacțiunea lor au contribuții semnificative în variația POX și a diferențelor dintre valorile medii. Constatăm că, în cazul VAT variaţia POX a fost mai puternic influențată de prezența infecției comparativ cu VMT, respectiv 18,2 și 4,2\% (Tabelul 2). 
Tabelul 2. Analiza varianței POX în funcție de genotip, infecție virală și repetiția biologică la infectare cu VMT sau VAT

\begin{tabular}{|l|l|l|l|l|l|l|l|l|}
\hline \multicolumn{1}{|c|}{ Sursa variației } & \multicolumn{1}{|c|}{ SP } & \multicolumn{1}{c|}{ CF } & GL & \multicolumn{1}{c|}{ F } & \multicolumn{1}{|c|}{ SP } & \multicolumn{1}{l|}{ CF } & GL & \multicolumn{1}{c|}{ F } \\
\hline VMT & 0,231862 & 38,9 & 4 & $21,20^{* * *}$ & 0,453344 & 35,3 & 3 & $31,56^{* * *}$ \\
\hline Genotip-A & 0,030167 & 5,1 & 1 & $11,03^{* * *}$ & 0,236135 & 18,4 & 1 & $49,31^{* * *}$ \\
\hline Infecție virală-B & 0,0049736 & 0,8 & 2 & 0,91 & 0,00982978 & 0,8 & 2 & 1,03 \\
\hline Repetiția & 0,088382 & 14,8 & 4 & $8,3 * * *$ & 0,225729 & 17,6 & 3 & $15,71^{* * *}$ \\
\hline A x B & 0,596413 & & 89 & & 1,28535 & & 68 & \\
\hline Total & & &
\end{tabular}

Răspunsul specific al genotipurilor la infectare cu virus a determinat și valori diferite ale contribuției infecției în funcție de virusul aplicat - VMT $(5,1 \%)$ sau VAT $(18,4 \%)$. Nu s-au stabilit diferențe semnificative între valorile medii în cazul repetițiilor biologice.

Un răspuns diferențiat și semnificativ al indicilor POX a fost stabilit pentru factorul tipul genotipului - sensibil, tolerant și grupul cu gene de rezistență faţă de VMT, în cazul infectării cu VMT (interacțiuni compatibile și incompatibile) sau VAT (interacțiuni compatibile), devansând după contribuție aportul factorului infecția virală - 39,8\% faţă de 15,2\% (Tabelul 3).

Tabelul 3. Analiza varianței POX în funcție de tipul genotipului (sensibil, tolerant, rezistent) la infectare cu VMT sau VAT

\begin{tabular}{|c|c|c|c|c|c|c|c|c|}
\hline Sursa variaţiei & SP & CF & GL & F & SP & CF & GL & F \\
\hline \multicolumn{9}{|c|}{ VMT } \\
\hline Infecție virală & 0,0607658 & 10,2 & 1 & $13,89 * * *$ & 0,195842 & 15,2 & 1 & $23,72 * * *$ \\
\hline Tipul genotipului & 0,151262 & 25,4 & 2 & $17,29 * * *$ & 0,511375 & 39,8 & 2 & $30,97 * * *$ \\
\hline Total & 0,596413 & & 86 & & 1,28535 & & 68 & \\
\hline
\end{tabular}

PPO. În mod similar algoritmilor expuși pentru POX au fost analizaţi factorii care contribuie la variaţia indicelui PPO. Analizând rezultatele obținute s-a constatat că, asupra indicilor PPO o contribuție semnificativă considerabilă o are genotipul, urmată de infecția virală și interacțiunea acestor factori, care au avut o conotație diferită în funcție de tipul infecției aplicate. Nu s-au stabilit diferențe statistice semnificative între valorile medii ale PPO pentru cele 3 repetiții biologice.

O particularitate relevantă este statutul genetic al genotipurilor analizate faţă de VMT (sensibil, tolerant şi rezistent). Astfel, contribuţia semnificativă în variabilitatea valorilor PPO în cazul infectării cu VMT în proporţie de $72,9 \%$ a fost pe seama genotipului şi doar 3,1\% pe seama diferenţelor între variate infectate și sănătoase $-3,1 \%$ (Tabelul 4). Totodată, în cazul infectării cu VAT a acelorași genotipuri s-a stabilit, de asemenea o contribuţie semnificativă de $29,1 \%$ a genotipului în variabilitatea PPO, 32,8\% a infecției virale şi $28,2 \%$ a revenit interacţiunii factorilor menționaţi.

Tabelul 4. Analiza varianței PPO în funcție de genotip, infecția virală și repetiția biologică la infectare cu VMT sau VAT

\begin{tabular}{|c|c|c|c|c|c|c|c|c|}
\hline Sursa variaţiei & SP & $\mathbf{C F}$ & GL & $\mathbf{F}$ & SP & $\mathbf{C F}$ & GL & $\mathbf{F}$ \\
\hline \multicolumn{4}{|c|}{ VMT } & & \multicolumn{4}{|c|}{ VAT } \\
\hline Genotip A & 0,229954 & 72,9 & 4 & $83,93 * * *$ & 0,109007 & 29,1 & 3 & $65,30 * * *$ \\
\hline Infecție virală B & 0,009750 & 3,1 & 1 & $14,23 * * *$ & 0,122925 & 32,8 & 1 & $220,93 * * *$ \\
\hline Repetiția & 0,0035738 & 1,1 & 1 & 2,61 & 0,003033 & 0,8 & 2 & 2,73 \\
\hline $\mathrm{A} \times \mathrm{B}$ & 0,014705 & 4,7 & 4 & $5,37 * * *$ & 0,105756 & 28,2 & 3 & $63,36^{* * * *}$ \\
\hline Total & 0,315325 & & 83 & & 0,375219 & & 71 & \\
\hline
\end{tabular}

O confirmare suplimentară a răspunsului diferențiat în funcție de tipul infecției virale e reflectată și în Tabelul 5, în cazul în care s-a analizat separat fiecare tip de interacțiune VMT - genotip sensibil, tolerant și rezistent.

Luând în calcul că 3 din 5 genotipuri erau purtătoare de gene de rezistență față de VMT, există o contribuție semnificativă a infecției virale asupra variabilităţii PPO $(4,6 \%, \mathrm{P} \leq 0,01)$, dar mult mai mică comparativ cu VAT $(32,8 \%)$, care se caracterizează printr-un grad mai mare de agresivitate asupra plantei, fapt ce rezultă și din figura $1 \mathrm{~B}$, unde sunt înregistrate valori ce depășesc de până la 1,6-3,2 ori martorul la infectare cu VAT și maxim de 1,3 ori mai mult la infectare cu VMT. Totodată, tipul genotipului la 
infectare cu VMT a contribuit cu 43,6\% în variabilitatea atestată, iar în cazul infectării cu VAT aceasta a fost determinată în proporție de $26,7 \%$.

Tabelul 5. Analiza varianței PPO in funcție de tipul genotipului la infectare cu VMT sau VAT

\begin{tabular}{|c|c|c|c|c|c|c|c|c|}
\hline Sursa variației & SP & $\mathbf{C F}$ & GL & $\mathbf{F}$ & SP & $\mathbf{C F}$ & GL & $\mathbf{F}$ \\
\hline \multicolumn{4}{|c|}{ VMT } & & \multicolumn{4}{|c|}{ VAT } \\
\hline Infectie virală & 0,014436 & 4,6 & 1 & $7,23 * *$ & 0,122925 & 32,8 & 1 & $54,90 * * *$ \\
\hline Tipul genotipului & 0,137419 & 43,6 & 2 & $34,39 * * *$ & 0,100046 & 26,7 & 2 & $22,34 * * *$ \\
\hline Total & 0,315325 & & 83 & & 0,375219 & & 71 & \\
\hline
\end{tabular}

\section{Concluzii}

Drept rezultat al celor expuse, putem stabili că, genotipul are contribuţie majoră în reacţiile defensive ale plantelor în cazul infectării virus. Totodată, răspunsul genotipului și contribuţia lui în variabilitatea activităţii enzimelor POX și PPO depind și de alţi factori, precum tipul virusului, statutul interacțiunii genotip-virus, iar acțiunea lor în complex determină în anumită măsură tendințe cumulative de amplificare sau diminuare a variabilităţii.

Indicele PPO a exprimat o specificitate mai mare de răspuns a genotipului în funcție de virusul aplicat comparativ cu POX. Totodată, s-a constatat că, VAT a avut o contribuție mai mare în variabilitatea POX și PPO, comparativ cu VMT.

Cercetările au fost realizate în cadrul proiectului Programului de Stat 20.80009.7007.04 „Biotehnologii și procedee genetice de evaluare, conservare și valorificare a agrobiodiversității”, finanțat de Agenția Naţională pentru Cercetare și Dezvoltare.

\section{Bibliografie}

1. BALINT-KURTI, P. The plant hypersensitive response: concepts, control and consequences. In: Mol Plant Pathol. 2019. Vol. 20(8), p. 1163-1178.

2. CLARKE, S., GUY, P., BURRITT, D., JAMESON, P. Changes in the activities of antioxidant enzymes in response to virus infection and hormone treatment. In: Physiologia Plantarum. 2002. Vol. 114(2), p. 157-164.

3. HERNÁNDEZ, J., GULLNER, G., CLEMENTE-MORENO M., et al. Oxidative stress and antioxidative responses in plant-virus interactions. In: Physiological and Molecular Plant Pathology. 2016. Vol. 94, p. 134-148.

4. TARANTO, F., PASQUALONE,, A., MANGINI G., et al. Polyphenol oxidases in crops: Biochemical, Physiological and Genetic Aspects. In: Int. J. Mol. Sci. 2017. Vol. 18 (377). doi:10.3390/ijms18020377.

5. MARCHANT, W., GAUTAM, S., HUTTON, S., SRINIVASAN, R. Tomato yellow leaf curl virus-resistant and - susceptible tomato genotypes similarly impact the virus population genetics. In: Front. in Plant Sci. 2020. Vol.11. https://doi.org/10.3389/fpls.2020.599697.

6. ISHIBASHI, K., ISHIKAWA, M. The resistance protein Tm-1 inhibits formation of a tomato mosaic virus replication protein - host membrane protein complex. In: Journal of Virology. 2013. Vol. 87(14), p. 7933-7939.

7. PANTHEE, D., BROWN, A., YOUSEF, G., et al. Novel molecular marker associated with Tm $2^{\text {a }}$ gene conferring resistance to tomato mosaic virus in tomato. In: Plant Breeding. 2013. Vol. 132, p. 413-416.

8. HU, Z., LIU, G., GAO, J., et al. Tomato Tm-2 $2^{2}$ gene confers multiple resistances to TMV, ToMV, PVX, and PVY to cultivated potato. In: Russian Journal of Plant Physiology. 2015. Vol. 62, p. 101-108.

9. HITCHBORN, J.H., Hills G.I. The use of negative staining in the electron microscopic examination of plant viruses in crude extracts. In: Virology. 1965. Vol. 27, p. 528-540.

10. ЕРМАКОВ, А.И., АРАСИМОВИЧ, В.В., ЯРОШ, Н.П. и др. Методы биохимического исследования растений. Л.: Агропромиздат. 1987. 430 с. 